\title{
The White Settlers' Experience of Exile and Alienation in Grenville's The Secret River
}

\author{
Ruzbeh Babaee \\ Faculty of Modern Languages and Communication, Universiti Putra Malaysia \\ rbabaei30@yahoo.ca \\ Arbaayah Ali Termizi \\ Faculty of Modern Languages and Communication, Universiti Putra Malaysia \\ Hardev Kaur A/P Jujar Singh \\ Faculty of Modern Languages and Communication, Universiti Putra Malaysia
}

\section{Doi:10.5901/mjss.2015.v6n2s1p521}

\section{Abstract}

\begin{abstract}
Literature has the capacity to create forms of history and memory that many historians and critics are not able to recognize. Kate Grenville's The Secret River portrays the history and culture of two nations. Grenville depicts the fiction in the form of history that belongs to her own ancestors. Grenville's novel gives her the chance to do a historical research that is from the history of her ancestors in 1805 to the realities that contemporary historians disclose about Australian settlers. In her historical fiction, Grenville depicts the exile, alienation, failure, success, dream, desire, and lifestyle of her own ancestors. Furthermore, through her novel, Grenville creates the opportunity to write on behalf of her ancestors as frontiers. In this respect, her act of writing in The Secret River is an act of revealing and solving some historical realities and mysteries with the help of the knowledge that she inherited from her own ancestors. The present study aims to explore these realities and in particular the exile and alienation of the white settlers in The Secret River.
\end{abstract}

Keywords: Exile, Alienation, History, Memoir, Settler, Aboriginal

\section{Introduction}

Through her work, Australian writer Kate Grenville shows her interest in considering the processes involved in writing fiction. Actually, it was her interest which led to writing of The Secret River (2005). Grenville in her writing turned into the colonial time, and considered the link between white and black in the years of founding the country.

The Secret River occurs around the Hawkesbury region near Sydney in the first two decades of the $19^{\text {th }}$ century. From one side, The Secret River illustrates the tragedy of Aboriginal people who were seen as enemy by the settlers. The author remarkably does not use jargon English for the Aborigines in the first visiting in order to create as much similarity with what would have been going on from the inhabitants' perspectives and the Aboriginal people of the region. From the other side, Grenville explores the issues such as exile and alienation of the settlers as the main motifs of her novel. She reveals the pains of her ancestors concerning exile and alienation of their homeland and their experience of the new land, culture, and people.

The Secret River tells the story of William Thornhill from London in England to New South Wales in Australia. When he was young, Thornhill worked very hard and got married Sal, his childhood sweetheart. However, he was financially broke and in order to provide his family he had to steal timber. Then, he had been imprisoned in England and consequently transported to New South Wales where he gained a hundred acres of land on the Hawkesbury River. Initially, Thornhill decided to be a waterman and make money to get back to London. Later he became interested in the land and decided to stay there, even though Sal did not like to be a settler and still had the dream of getting back to England.

In knowing how to concern the unknown colonial environment, the Thornhills are also involved in tensions between immigrants and the Aboriginal residents of the region. As these tensions aggravate, the Thornhills have to talk about their relationships with both the native Aboriginal people and with their English settler-neighbors.

Thornhill does not know whether he should defend his land violently towards Aboriginal or comes to a state of 
compromise. Finally, the tensions get critical and aggravated and the settlers decide to stay together against the Aboriginal people. This decision is successful enough to permit them to continue to dwell in the land without fear of the Aboriginal people's attack. Later Thornhill makes a lot of money and buys many lands. He makes a big house and attempts to provide a comfortable life for Sal. He attempts to convince Sal that their life is so much connected to New South and they must forget returning back to England.

Grenville depicts the history of her ancestors, not as a historian but as a novelist. The part of history that Grenville sheds light on belongs to the history of exile and alienation of her own grandfathers and grandmothers. She tells her own memoirs; as George Vidal believes: "A memoir is how one remembers one's own life" (Palimpsest, 1996). Grenville sees exile and alienation as the memoir of her own life but in a fictional manner. She reflects the exile and alienation in a colonial and postcolonial discourse that she and her own ancestors have experienced. Grenville's story is not an autobiography or a history from her childhood to adolescence, but it is the memoir of a particular time of exile and alienation, as Baker and Zinsse make distinction between memoir and autobiography, they states:

Unlike autobiography, which moves in a dutiful line from birth to fame, memoir narrows the lens, focusing on a time in the writer's life that was unusually vivid, such as childhood or adolescence, or that was framed by war or travel or public service or some other special circumstance (1998: 15).

For Grenville the memoir focuses on a time of her ancestors' exile and alienation that were framed in New South Wales. The present paper attempts to investigate the exile and alienation of the settlers in The Secret River. This study demonstrates that Grenville's own experience of exile and alienation is reflected through the fictional settlers in The Secret River.

\section{Portrayal of History}

In addition to writing on different topics such as male/female relations, nature, and environment, Grenville has devoted some of her fiction to the history of Australia- especially the first encounters between Indigenous Australians and white settlers.

Grenville published her first work as a collection of short stories called Bearded Ladies (1984). In this collection, she shows women in different roles in the male world. After that she published some fiction sharing the theme of gender relations. She published The Idea of Perfection (1999) that is a 'love story' tracing and exploring the relationships between male and female. Then, she published Joan Makes History (1988) that is a parody of the history of Australia written from a female's view point. She also published The Lieutenant (2008) that narrates the interaction of a soldier from the First Fleet with the indigenous inhabitants of Australia.

Although being recognized as Grenville's most successful novel, The Secret River has been criticized by some historians and literary critics. For instance, Clendinne devoted a significant part of her Quarterly Essay to a historiographic criticism of The Secret River. She argues that, contrary to Grenville's claim, The Secret River is not history. As Clendinnen states:

"We need history, not Black Armband history and not triumphalist white-out history either, but good history, true stories of the making of this present land, none of them simple, some of them painful, all of them part of our own individual histories. (1999: 102-103)"

Furthermore, according to Adam Gall, "Grenville represents the novelist as trying to produce an empathetic history of settlement, but also trying to step back and allow the story of the place to appear" $(2008,96)$. In the novel, Grenville takes the reader back in time. Grenville herself states:

"I hoped to create an experience for a reader in which they could understand what that moment of our past was really like. The great power of fiction is that it's not an argument: it's a world. Inhabit it for a while and you are likely to come out a little changed. (2006: 152-153)"

In addition to reading theoretical texts, Grenville understood that she required exploring and visiting the places where she wanted to write about. She confesses in an interview that she is a "great believer in the experiential theory of writing" (Grenville, Interview). In fact, she illustrated Australian history which is full of mysteries. According to Behrendt:

"Grenville's symbolism is a striking reminder of the history that lies beneath our modern Australian state and of the ways in which that history has sometimes been deliberately suppressed to give the impression of more noble beginnings (2006: 4)." 
The main theme of this fiction is the conflict between two cultures and races. As Kelada argues,

'Grenville's texts are 'arguments' and 'worlds' whose representations of race and power relations offer important insights into the strategies and performance of whiteness in Australian contemporary literature, particularly in relation to the idea of the 'reconciliation' between white Australians and Indigenous peoples. (2010: 1)"

The British settlers have to coexist with the Aboriginal people of Australia, but both groups have lack of communication and understanding. Moreover, some critics read the novel as an unpleasant illustration of the massacre of indigenous people. For instance, Kossew describes "Grenville's fiction as "a reassessment of what it means to be a white Australian". Kossew continues that "in so doing, she is situating her novel as a reworking of the narrative of settlement with a contemporary sensibility" (2007: 9). She argues:

\begin{abstract}
"Grenville sees her novel as standing "outside that polarized conflict" of right and wrong by providing instead an empathetic and 'imaginative understanding of those difficult events' (Grenville in an interview with Ramona Koval). It is only by uncovering the painful scars of the past, the text suggests, by voicing the "Great Australian Silence", which a process of reconciliation and shared belonging can begin. But even then, from her own positionality as a "white" Australian, it is hedged about by moral ambiguities. (2007: 17)"
\end{abstract}

Kossew considers moral ambiguities that the novel generates. However, Grenville describes many of these ambiguities of her fiction in The Secret River in Searching for the Secret River (2006), which allows the reader to find the background and origin of the novel.

In spite of these criticisms, Grenville attempts to be even-handed. She admits the difficulty of writing on the Aboriginal people: "That was tricky because what I didn't want to do was to step into the heads of any of the Aboriginal characters" (Grenville, Interview). The Secret River is a balanced illustration of the Aboriginal people and white settlers.

While previous studies mostly considered the clash between the Aboriginal people and white settlers, or explained the issues that the Aboriginal people faced with in The Secret River, the present study aims to explore the white settlers' experience of exile and alienation. In fact, this study finds exile and alienation as two critical issues that most immigrants have been encountered not only in fictional work such as The Secret River, but also in the reality.

\title{
3. Exile and Alienation of the White Settlers
}

In Reflection on Exile (2000), Edward Said states that "Exile is strangely compelling to think about but terrible to experience" (2000: 137). Exile has been an intricate issue for the writers and critics who have experienced it. The motif of exile attracts many authors' imagination in the field of literary history, since they have the experience of leaving their homeland for various reasons. In fiction, as in life, there are different types of exile that people have experienced and written about.

Martin Tucker, Edward Said, Celeste Schrenck, and many others have considered and written about the figures of exile. For instance, Schenck explored the particular displacement experienced by female scholars in exile. Samuel Gladden examined the writing of Oscar Wild as following his imprisonment and moving to France. Leo Gurko depicted Joseph Conrad's writing and experience in exile. Edward Said also observes that both literature and history reflects exile. According to him: "While it is true that literature and history contain heroic romantic, glorious, even triumphant episodes in an exile's life, these are no more than efforts meant to overcome the crippling sorrow of estrangement" (2000: 137).

Grenville in The Secret River tells about the exile of the people and among them her ancestors who emigrated from London to New South Wales. Grenville first depicts the people's lifestyle in London late nineteenth century and then presents their exile in New South Wales. Grenville tends to make the reader think about the concept of exile as she has seen and experienced. She begins her story with Thornhill who remembers his childhood in the slum of London, and his attempt to keep himself preserved in an overpopulated city where disease is popular, life expectations are contemporary and social support is nonsense. By depicting the young William's childhood friends as "all thieves, any time they got the chance" (The Secret River, 16), Grenville addresses both the boys and the society in general. Stealing was often a style of life and entertainment for the boys and people in that ill society, as the young William states, "there could be no sin in thieving if it meant a full belly" (The Secret River, 16).

Although in the novel, London is not the central setting, it brings William's life as a settler into context, and provides the ground for description of the conflicts he encounters in a colonial landscape and environment.

In New South Wales, Thornhill must learn to manage the poverty and the miseries, instead of fighting against them and making the conditions worse. He must learn to adopt himself with the new situation, convention, and culture that, 
according to Said, is "in large part the work of exiles, émigrés, refuges" (2000: 137).

Grenville very beautifully illustrates the differences between Thornhill's London and the new land. Whereas London was an overcrowded city with no individual space, Thronhill finds enough empty vast lands in New South, although quickly he understands that the lands belong to the Aboriginal people.

Furthermore, through Sal, the writer investigates the displacement experience of the people who immigrated to the new land. Sal works hard and never complains about the new situation, but settling their new life in Australia has gone with difficulty to her. Sal experiences exile as "the unhealable rift forced between a human being and a native place, between self and its true home: its essential sadness can never be surmounted" (Said 2000: 137).The trees, environment, and weather tell Sal that she is no longer at her homeland. She feels the pressure of the new land on herself. In fact, it is the pressure of exile that makes the condition intricate for her. She feels homesick for the smells and vision of her homeland. Indeed, exile has torn Sal "from the nourishment of tradition, family and geography" (Said 2000: 138).

While Thornhill attempts to make his life on the new land, Sal sees it difficult to modify since she did not bear the same amount of mortification that her husband did. Sal adheres to her past in Britain, reimagining her life in her homeland as much as possible. The writer employs Sal to examine the emergence of British culture in Australia and the persisting notion that England was Home and the new land was exile. Grenville sees her own fate through Sal. In fact, Grenville is a writer of exile. In Reflection on Exile, Said refers to Faiz Ahmad Faiz, Pakistani writer, who

"was exiled from his native Pakistan by Zia's military regime, and found a welcome of sorts in strife-torn Beirut. Naturally his closest friends were Palestinian, but I sensed that, although there was an affinity of spirit between them, nothing quite matched- language, poetic convention, or life history (2000: 138)."

Grenville like Faiz sees the differences in culture, language and convention between her own land and the new land. She shows her suffering through the characters of her fiction. Thornhill understands that he has lost the life he left in Britain forever. While in jail in London and sentenced to death, Thornhill was thinking about escaping the loop. But now, he was trapped on a land thousands miles far away from his homeland, in the mid of water. He suffers from exile, of being separated from his past and imagination.

Grenville depicts exile as a painful problem that many immigrants in Australia have faced it. Exile is like a nightmare for Thornhill, Sal and Grenville. When one finds himself/herself in exile he/she has no interest and involvement in that land and attempts to escape from the exile through different ways such as recalling his/her past memories or making dream for future. According to Said, "Exiles are cut off from their roots, their land, their past...Exiles feel, therefore, an urgent need to reconstitute their broken lives, usually by choosing to see themselves as part of triumphant ideology or a restored people". Said concludes that "the crucial thing is that a state of exile free from this triumphant ideology- designed to reassemble an exile's broken history into a new whole- is virtually unbearable, and virtually impossible in today's world". Then he gives some examples of "the fate of Jews, the Palestinians and the Armenians" (2000: 140-141). Thus the Thornhills have no way, just to accept the reality of their exile.

Thornhill's childhood and youth in London is covered by poverty which leads him to the crime for which he is convicted to exile, but he keeps the same social values which have turned him an outcast in his homeland England. However, unlike Sal, Thornhill does not like to get back to London; he still desires to remake for himself the life of the English man in the new land, but all the resources and facilities for creating such a life is far away from his hand. Soon after he settled on what later was named Thornhill's place, he determines the area in which he tends to grow his crops:

"In the centre of the clearing he dragged his heel across the dirt four times, line to line. The straight line and the square they made was like nothing else there and changed everything. Now there was a place where a man had laid his mark over the face of the land. It was astonishing how little it took to own a piece of the earth. (The Secret River, 134)"

Thronhill easily closes his eyes on the clear emblems of the existence of last land owners. His son Willy refers to the time they begin plowing the soil: "Look Da... some other bugger already digged it up." (The Secret River, 140). Later, the blacks' afford to take over their land results eventually in their massacre by the white people. However, Thornhill sees himself as the English gentleman that he has dreamed to be:

"The Irishman Devine had built a fine stone house for Mr. Thornhill [...]. They had named it Cobham Hall [...]. Devine was full of ways to make the place a fortress. The eminence itself was the start of it. A hundred of the buggers could not cut you off here he had assured. The walls were to be of stone, half a yard thick... Cobham Hall was a gentleman's residence." (The Secret River, 316)" 
In spite of Thornhill's feeling of success there is a deeper feeling of loss that is the sense of exile. After the attack, there is just a black survivor, Jack, who gets back to prove his right of ownership. However, Thornhill attempts to satisfy Jack, but Jack sticks to his idea: "No", he stated. Jack put his hand on the floor strongly and said "My place" (329). In this moment, Thornhill comes to the understanding about the hollowness of his acquisitions:

\begin{abstract}
"He would have said he had everything a man could want, but there was emptiness as he watched Jack's hand caressing the dirt. This was something he did not have: a place that was part of his flesh and spirit. There was no part of the world he would keep coming back to, the way Jack did, just to feel it under him. It was as if the very dirt were consolation. (The Secret River, 329)"
\end{abstract}

Thronhill realizes that in exile nothing is secure and sees exile as a situation of terminal loss. He sees his alienation that, according to Coser in Masters of Sociological Thought, is a "condition in which men [and women] are dominated by forces of their own creation, which confront them as alien power" (1977: 50). In short, the creation rules over the creator. Furthermore, according to Eric Fromm in Marx's Concept of Man,

\begin{abstract}
"Alienation means, for Marx, that man does not experience himself as the acting agent in his grasp of the world, but that the world (nature, others, and he himself) remain alien to him. They stand above and against him as objects, even though they may be objects of his own creation. (1995: 44)"
\end{abstract}

Alienation is the emotional isolation not only from others, but also from the homeland, dreams, and memories. In Grenville's novel, the Thornhills feel alienated in spite of their ownership in the new land. Grenville presents different kinds of alienated settlers. On one side, she shows the "good settler" like Tom Blackwood who believes "Give a little, take a little, that's the only way" (The Secret River, 108). Blackwood is in good terms with natives, and even he suggests that Thornhill pursues the same policy regarding the Aboriginal people. On the side, there is the cruel person like Smasher, who is in Broken Bay, and is accused of the rape and assassination of several Aboriginal people. Thornhill keeps a mediator position, and is worried to be someone like Smasher, but finally, gets involved in the assassination of the Aboriginal people. Following the murder, the novel obviously depicts the results such as gain and loss for Thornhill. The passage of time brings a climate of tranquility which results in Thornhill's approval of his ownership of the land, in spite of his feeling of hollowness. Furthermore, it is a loss, as of one of his sons, who accepts the culture of the Aboriginal people, decides to live with the good settler, Tom Blackwood. All of these demonstrate Grenville's cultural-historical concern in her novel.

\title{
4. Conclusion
}

Grenville illustrates the Aboriginal culture conflicts with its British counterpart. Although the novel represents Thornhill's journey from London to New South West, Grenville puts almost equal weight on the Aborigines and their lifestyle. Apparently, the events and characters of The Secret River are grown in Grenville's soul and blood. She reflects the exile and alienation of her ancestors from their homeland.

Grenville reflects the cultural alienation of her ancestors in the new land where they are falling apart not only from their own land but also from their culture. Grenville's fiction is part of the history that she had kept within her own heart before publishing it. In fact, before the manifestation of her novel, she lived within her own exile and alienation, but through The Secret River, Grenville emancipates herself from both of them at least mentally, if not physically.

Grenville attempts to show that The Secret River is not judgment on any of her characters and their actions, just reveals the reader the consequences of their actions. The Secret River shows Grenville's attitude towards exile and alienation as two destructive elements that affect the life of both settlers and indigenous.

\section{References}

Baker, R., \& Zinsser, W. K. (Eds.). (1998). Inventing the truth: The art and craft of memoir. Houghton Mifflin Harcourt.

Behrendt, L. (2006). "What Lies Beneath." Meanjin 65(1): 4-12

Clendinnen, I. (1999). "True Stories." Boyer Lectures 1999. Sydney: ABC Books

Coser, A. L. (1977). Masters of Sociological Thought. $2^{\text {nd }}$ ed., NY: Harcourt Brace.

Fromm, E. (1995). Marx's Concept of Man. NY: Continuum.

Gall, A. (2008). "Taking/Taking Up: Recognition and the Frontier in Grenville's The Secret River. JASAL. Especial Issue: The Colonial Resent

Greenville, K. (2005). The Secret River. The Text Publishing Company 
--- (2005). Interview with Ramona Koval. Radio National 17 July

--- (2006). 'Secret River- Secret History' in The Sydney Papers, Summer: 149-53.

Kelada, O. (2010). "The Stolen River: Possession and Race Representation in Grenville's Colonial Narrative." Journal of the Association for the Study of Australian Literature, 10.

Kossew, S. (2007). 'Voicing the 'Great Australian Silence': Kate Grenville's Narrative of Settlement in The Secret River'. Journal of Commonwealth Literature 42(2): 7-18.

Said, E. (2000).Reflections on Exile and Other Essays. Harvard University Press.

Vidal, G. (1996). Palimpsest. Penguin 